\title{
DNA testing for high risk of prostate cancer
}

\author{
Dominika Wokołorczyk \\ From Annual Conference on Hereditary Cancers 2010 \\ Szczecin, Poland. 10-11 December 2010
}

Association studies of candidate genes in DNA repair and cell cycle control pathways identified mutations associated with a susceptibility to prostate cancer in BRCA1, BRCA2, CHEK2, NBS1 and BRIP1 genes. Mutations in these genes confer 1.5- to 6-fold increase in the risk of prostate cancer. In general, the risks associated with these mutations are higher in carriers who report family history of prostate cancer (the risk increased 3to 15 -fold).

Our studies confirm that rare mutations in DNA damage repair genes are associated with a predisposition to prostate cancer. Specific mutations in NBS1, BRCA1 and CHEK2 genes are associated with 1.6- to 4.6-fold increased risk for prostate cancer in the Polish population. The risk is higher, increased approximately $5-15$ fold, in carriers who report prostate cancer in at least one first and/or second degree relative.

In the past three years, new DNA markers of low penetration for prostate cancer were identified by GWAS studies. Of these markers, the strongest association with disease risk was seen for markers of chromosome $8 \mathrm{q} 24$. We analyzed how markers of this region influence prostate cancer risk in a in a series of cases and controls from Poland. Single markers of 8q24 were associated with a low penetrance for prostate cancer approximately 1.5- fold increased risk (ORs ranged from 1.4 to 1.6). Carriers of two different markers had the risk increased on average by 2,5 -fold. Carriers of risk alleles of three markers had on average 6-fold increased risk. Carriers of five markers of $8 \mathrm{q} 24$ had an odd ratio of 10.7 for prostate cancer (95\% CI 3.3 - 36).

Published: 12 January 2012

Correspondence: dominikawok@o2.pl

International Hereditary Cancer Center, Pomeranian Medical University, Szczecin, Poland

(c) 2012 Wokołorczyk; licensee BioMed Central Ltd. This is an open access article distributed under the terms of the Creative Commons Attribution License (http://creativecommons.org/licenses/by/2.0), which permits unrestricted use, distribution, and reproduction in any medium, provided the original work is properly cited.
doi:10.1186/1897-4287-10-S1-A12

Cite this article as: Wokołorczyk: DNA testing for high risk of prostate

cancer. Hereditary Cancer in Clinical Practice 2012 10(Suppl 1):A12. and take full advantage of:

- Convenient online submission

- Thorough peer review

- No space constraints or color figure charges

- Immediate publication on acceptance

- Inclusion in PubMed, CAS, Scopus and Google Scholar

- Research which is freely available for redistribution 